تأثير تنظيم كنندهاى رشد سيتوكينينى بر باززايى مستقيم پنج رقم سيبزمينى

بتول رحيميان'، محمد ربيعى " و محمود خدامباشى"

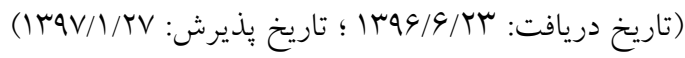

جكيده

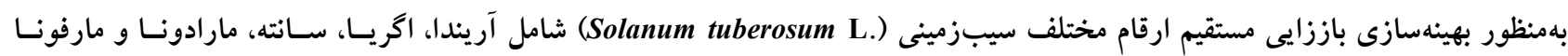

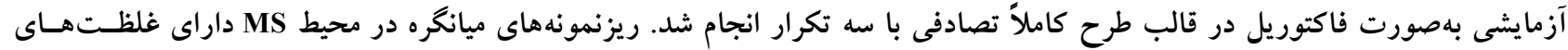

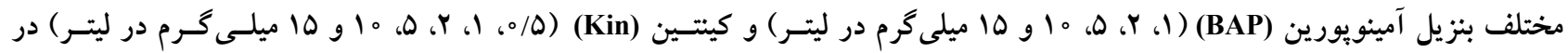

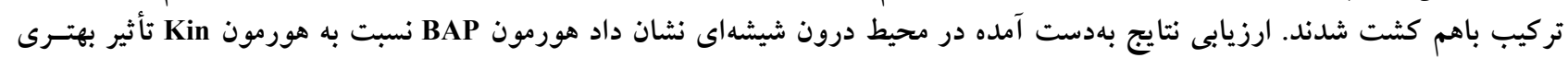

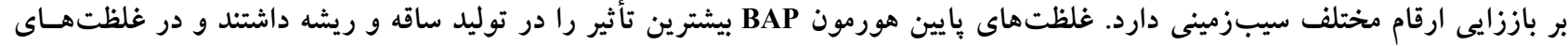

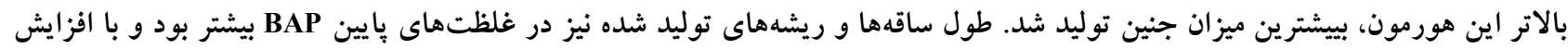

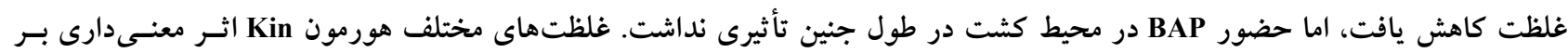

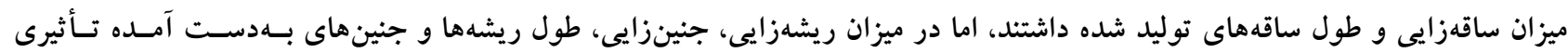

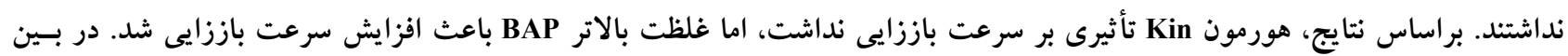

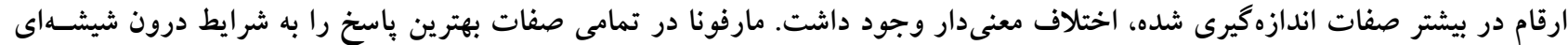

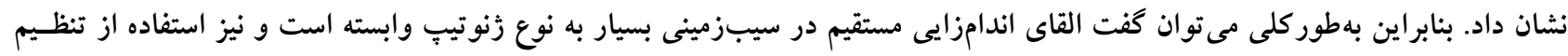

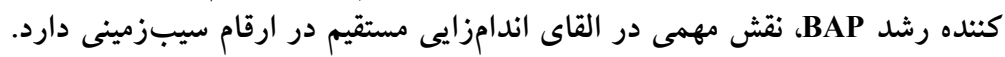

وازمهاى كليدى: اندامزايى، كشت كالوس

ا، ؟ و ؟. بهترتيب دانشجوى سابق كارشناسى ارشد، استاديار و استاد، كروه اصلاح نباتات و بيوتكنولوزى، دانشكده كشاورزى، دانشخاه شهركرد

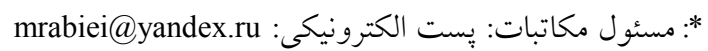


محيط كشت با توجه به رقم مورد استفاده بسيار متفاوت اسـت،

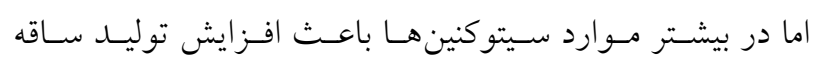

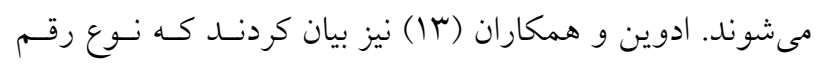

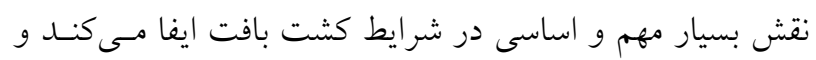

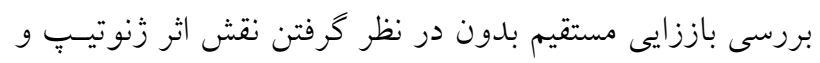

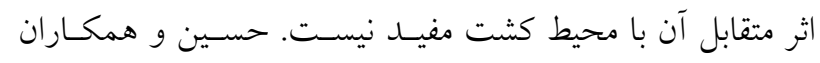

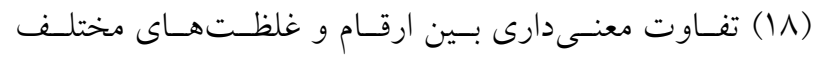

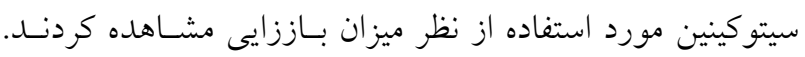

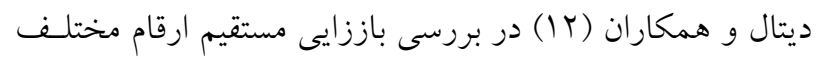

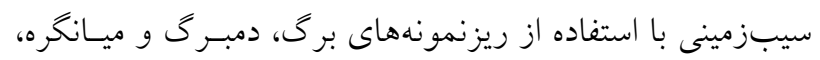

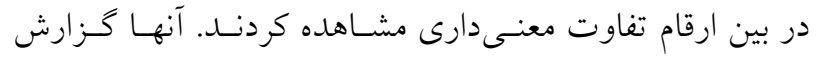

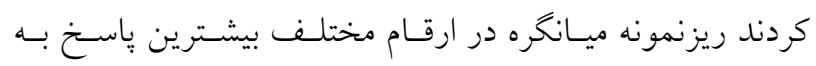
باززايى ساقه و ريشه را در تركيبـات مختلـف هورمـونى نشـان

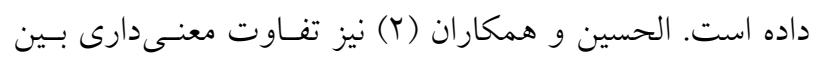

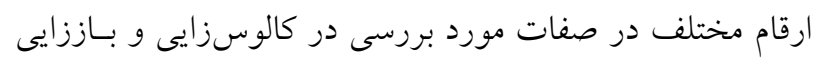

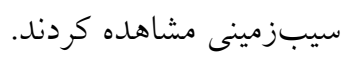
تحقيقات زيادى براى دستيابى به روشى براى باززايى درون

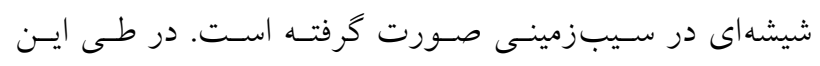

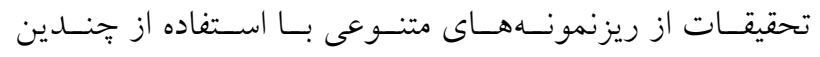

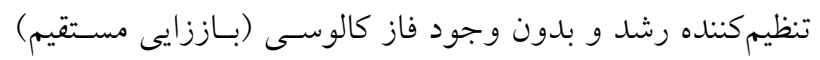

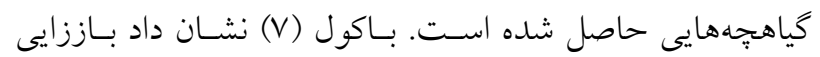

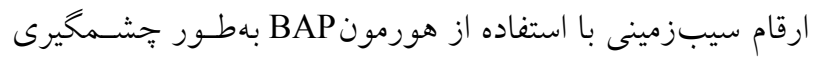

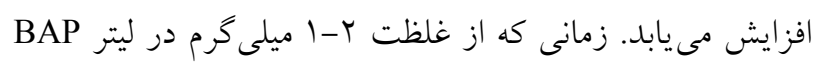

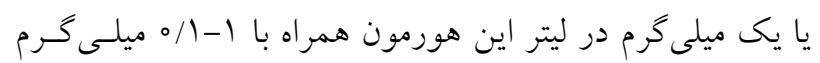

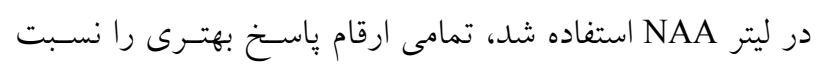

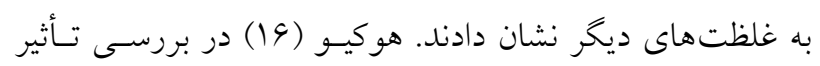

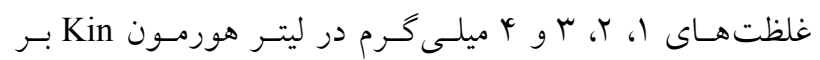

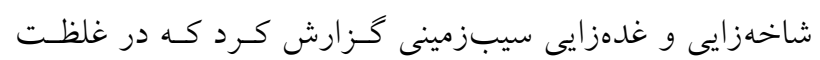

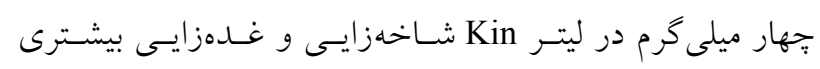

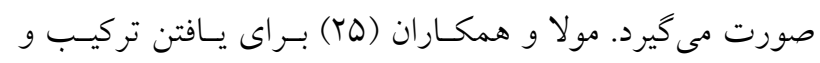

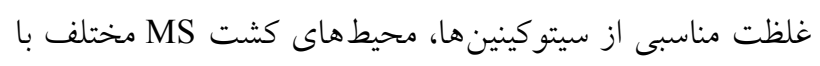

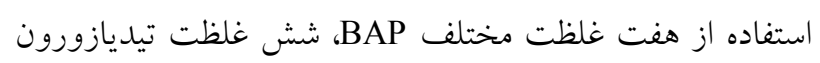

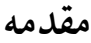

سـيبزمينسى (Solanum tuberosum L.) يكسى از محصـولات غذايى مهم مردم دنيا است كه از نظـر اقتصـادى در بسـيارى از

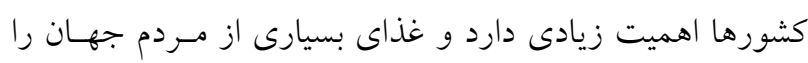

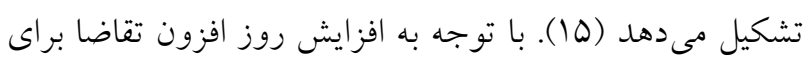

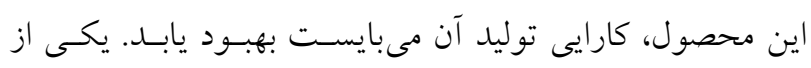

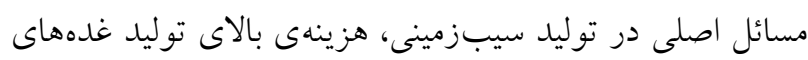

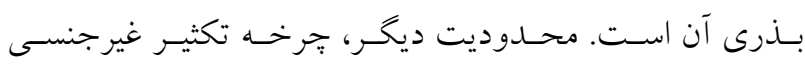

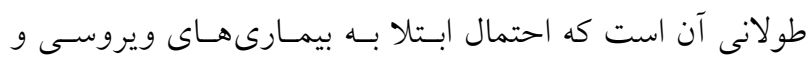

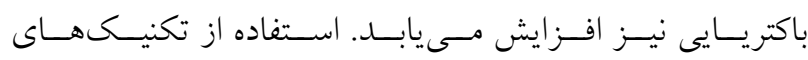

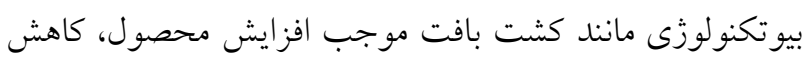

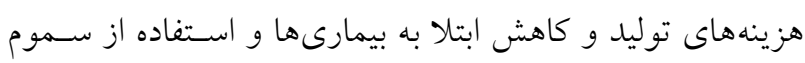

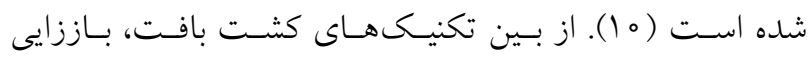

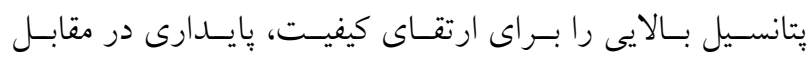

بيمارىها و ويزّكىهاى كشاورزى سيبزمينى، داراست (19).

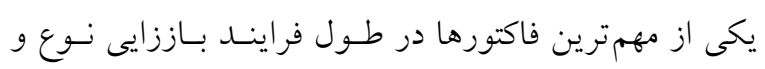

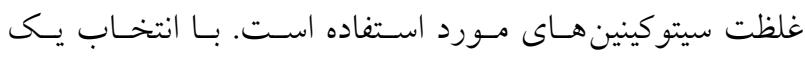
سيتوكينين مناسب ممكن است توانايى اندامزايى ريزنمونهها نيز

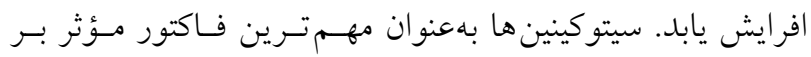

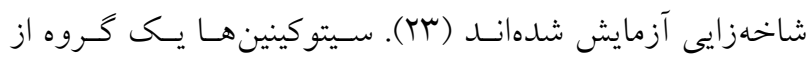

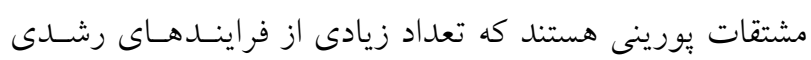

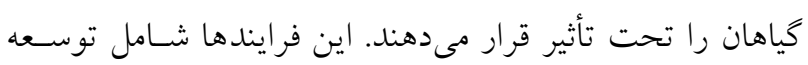

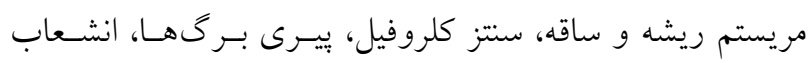

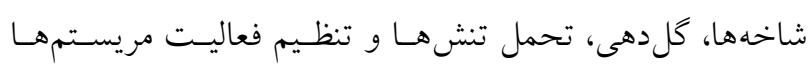

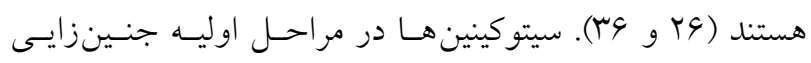

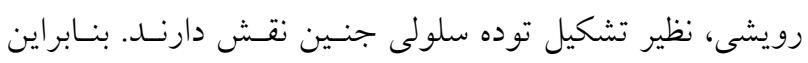

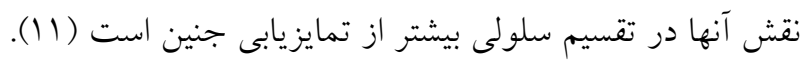

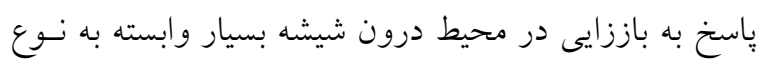

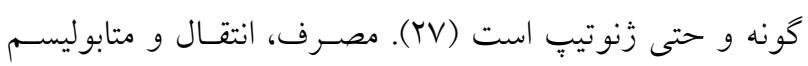

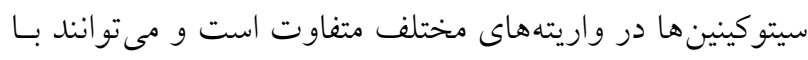

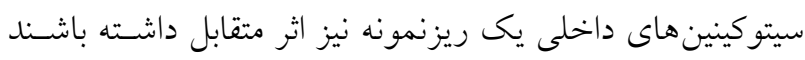

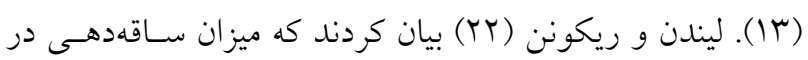




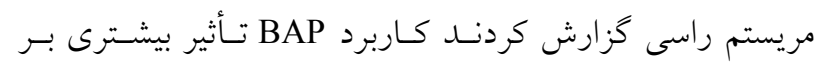
باززايى مستقيم سيبزمينى داشته است.

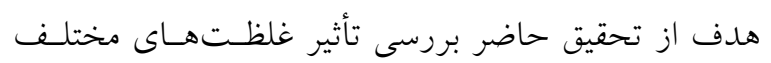

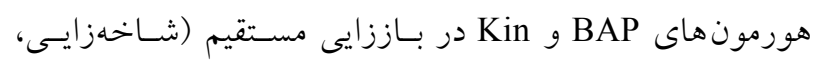

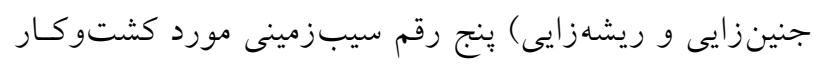

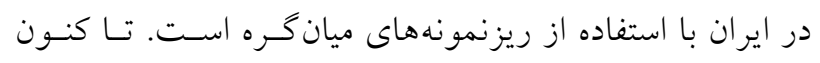

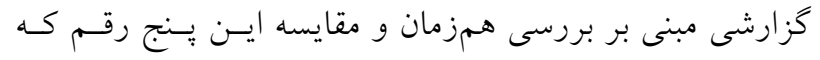

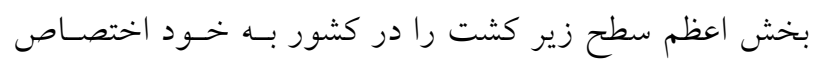

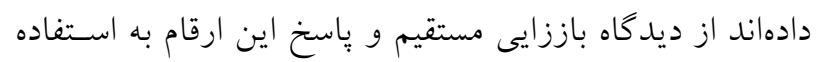
صرفا سيتوكنينها در شرايط كشت درون شيشه ارائسه نشـده

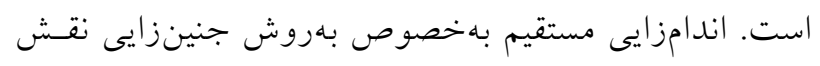

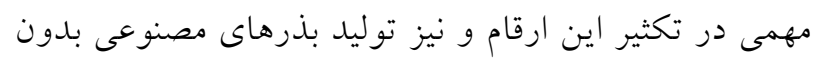

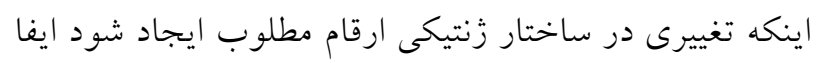

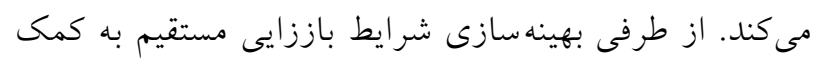

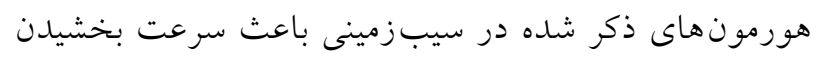

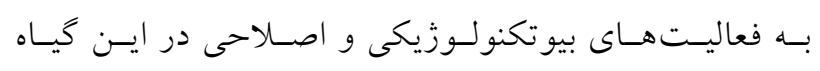
مىشود.

\section{مواد و روشها}

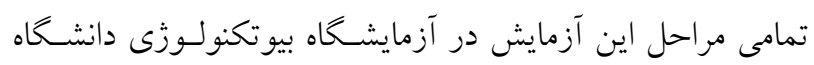

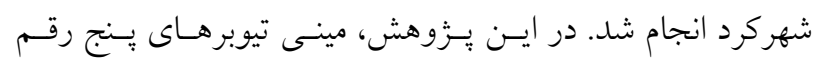

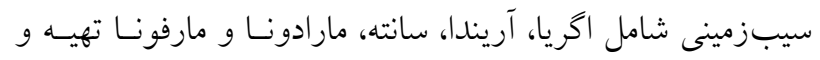

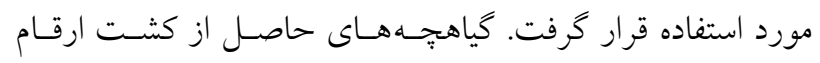

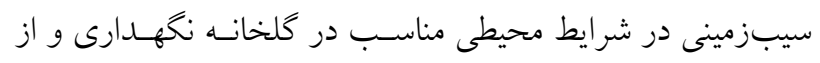

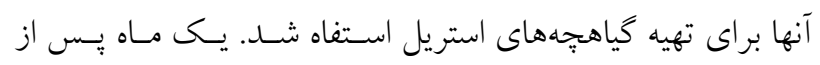

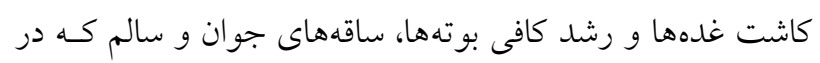

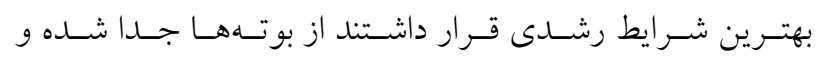

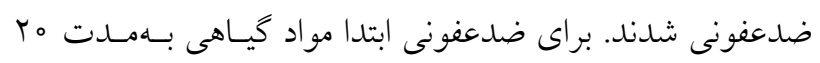

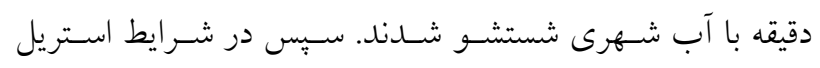

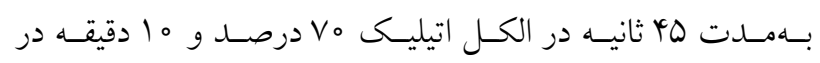

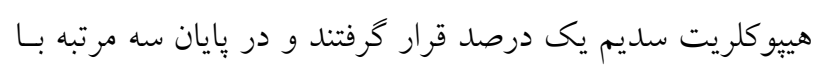

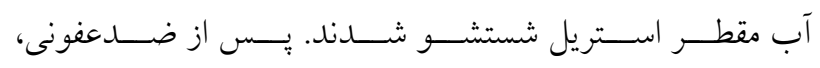

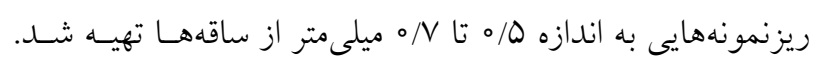

و هشت غلظت زآتينريبوزيد بهطور جداكانه مورد استفاده قرار دادند و كزارش كردند كه در بين هورمونهـاى مـورد استفاده،

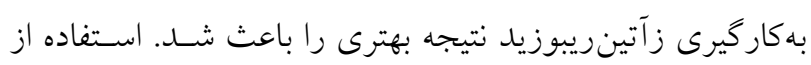

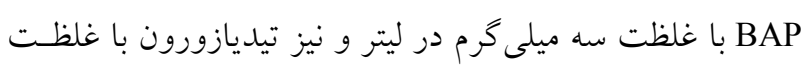

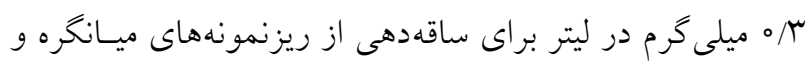

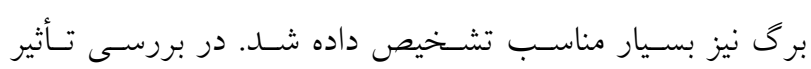

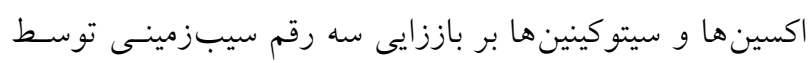

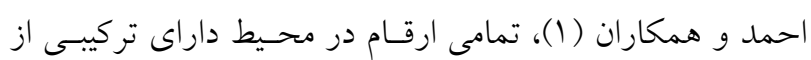

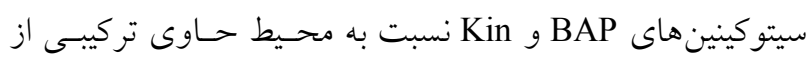

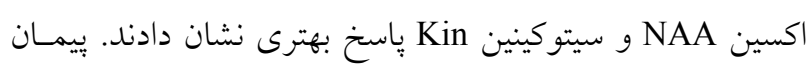

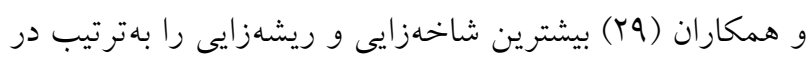

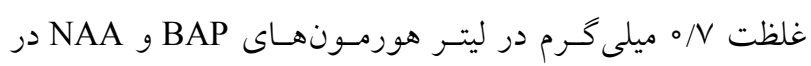
ارقام مختلف سيبزمينى بهدست آوردند. بويـان (N) بـهمنظـور

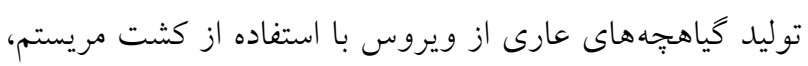
در سه رقم سيبزمينس تـأثير سـيتوكينينهـاى BAP و

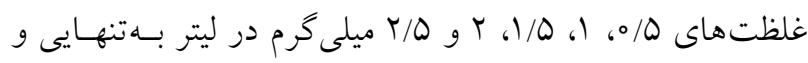

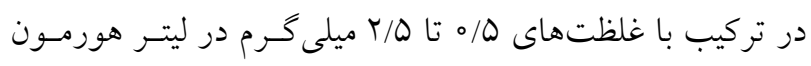
BAP مورد بررسى قرار داد. وى گزارش كرد كه هورمون GAr

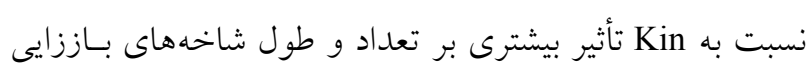

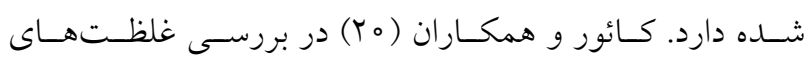

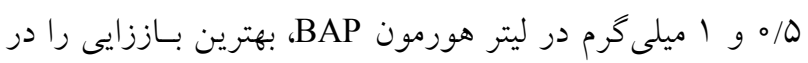

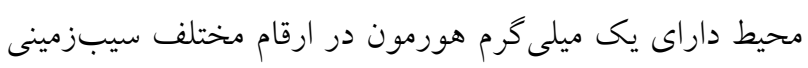

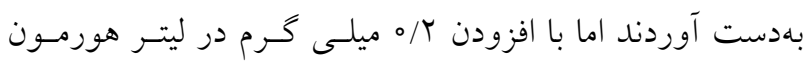
GAr به محيط كشت، كاهش جشمخيرى در شـاخهزايسى ارقـام

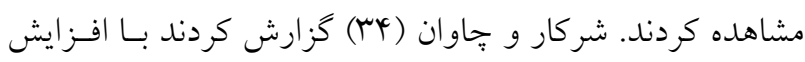

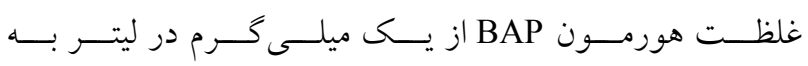

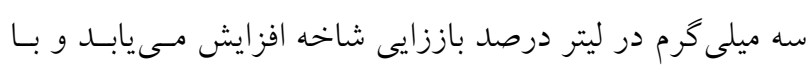

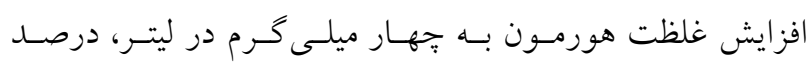

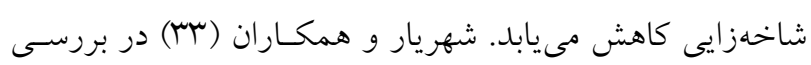

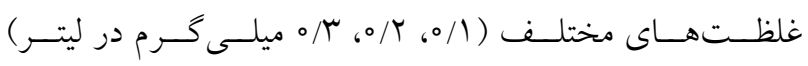
هورمسونهـاى BAP و GAr بـهـصـورت جداءانسه در بـاززايى

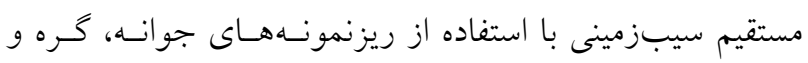


بيانكر وجود تفاوت بسيار معنىدارى در بين ارقـام بـود (جـدول

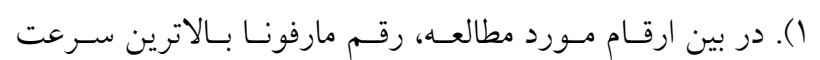

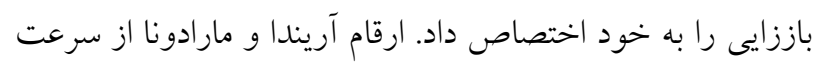

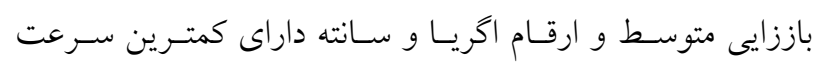

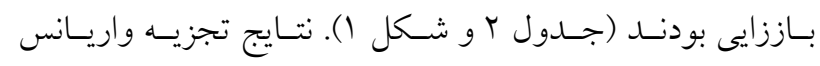

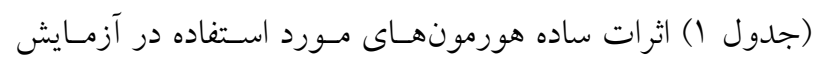

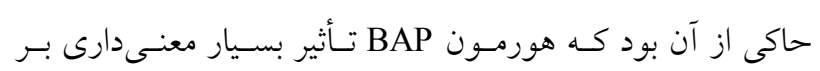

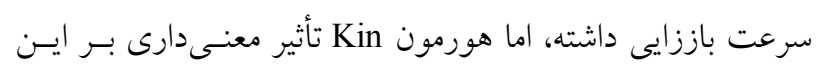

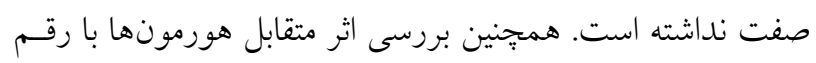

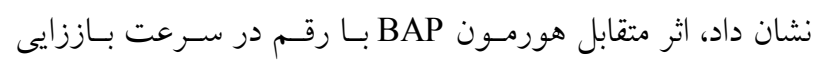

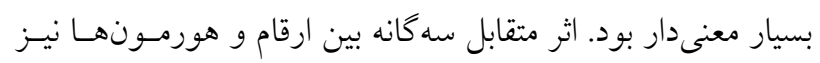

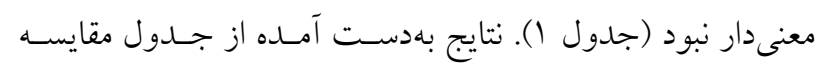

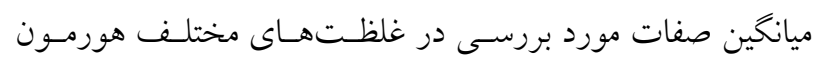

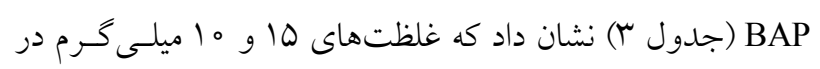

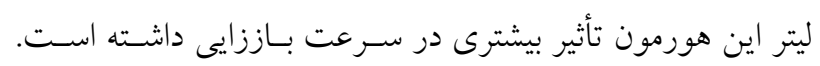

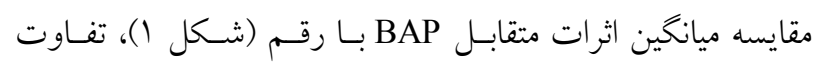

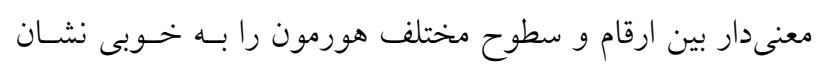
داد. در غلظت دو و ينج ميلى گرم در ليتر سـرعت بـاززايى ارقـام

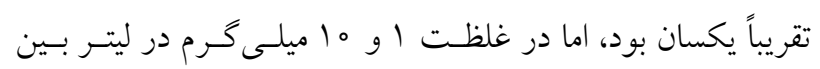

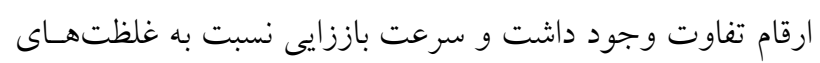

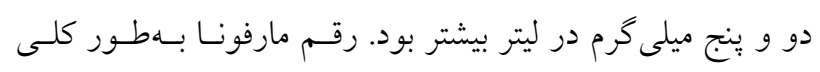

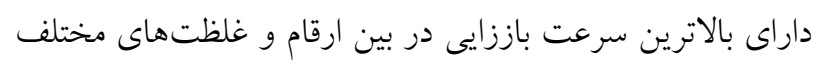

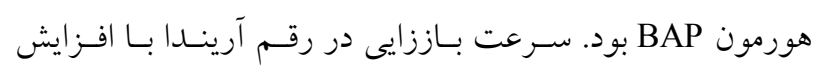

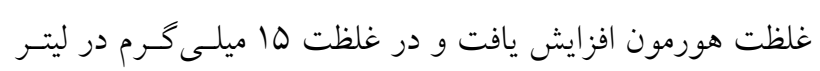

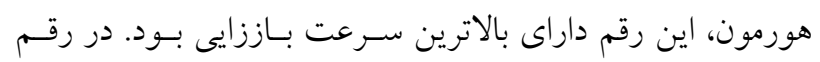

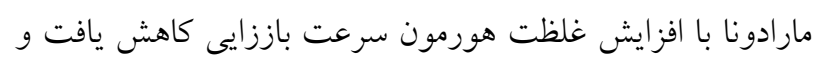

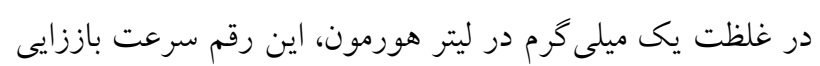

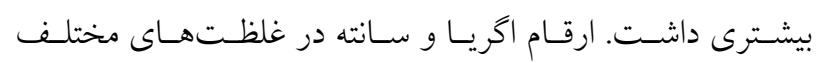

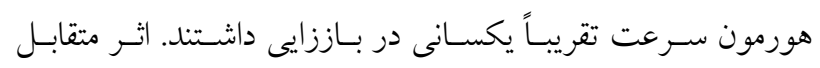

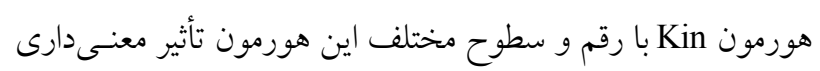

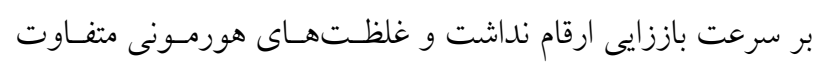
تأثير يكسانى بر سرعت باززايى داشتند (جدول بارئ.

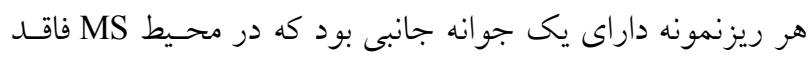

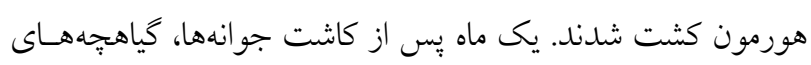

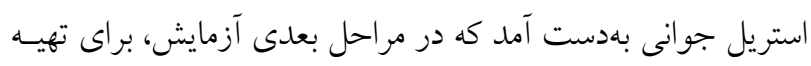

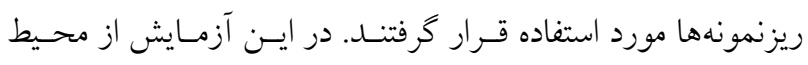

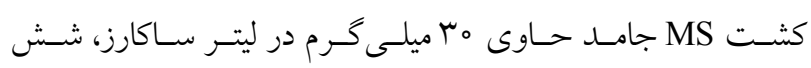

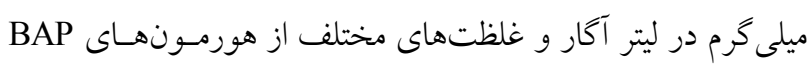

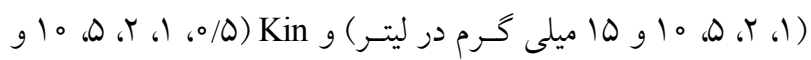

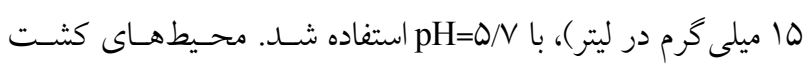

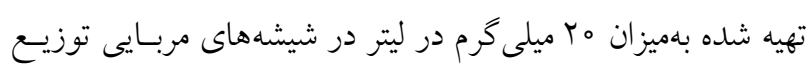

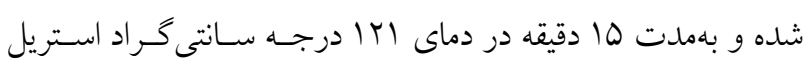

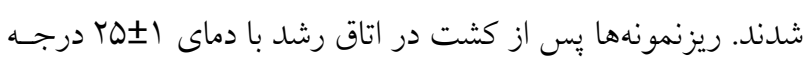

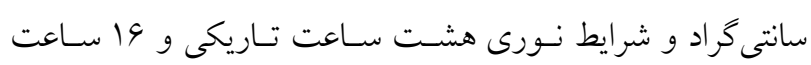

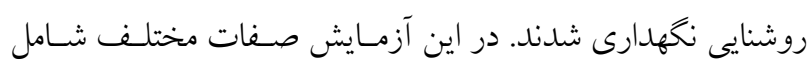
سرعت باززايى (براساس تعـداد روز از شـروع كشـت تـا مشـاهده

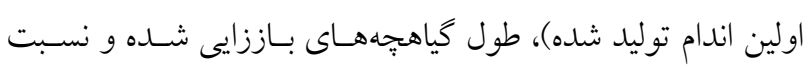

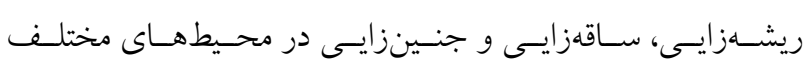

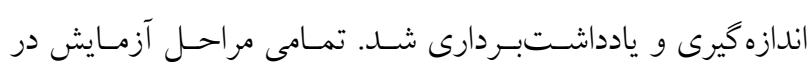

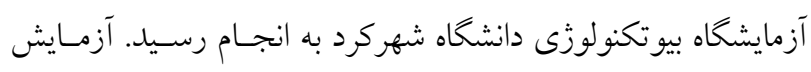

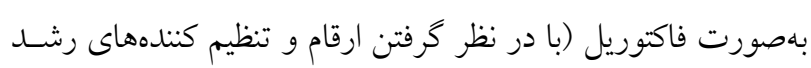

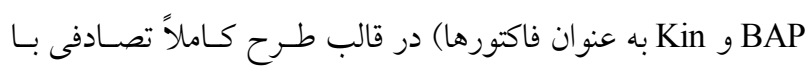

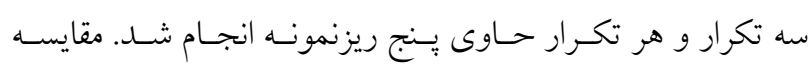

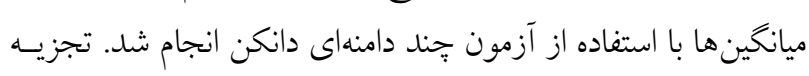

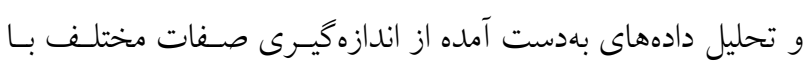

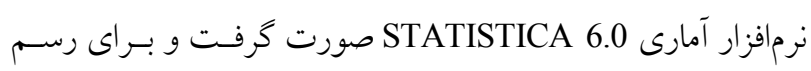

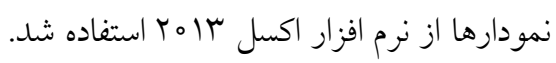

\section{نتايج و بحث}

اثرات نوع و غلظتهاى مختلف هورمونهاى اسـتفاده شـــه در اين بزوهش به تفكيك صفات اندازهيرى شده، گزارش و مورد بحث قرار كرفته است.

سرعت باززايى تجزيه واريانس دادهها براى سرعت باززايى در تيمارهاى مختلف باريى 
جدول ا. نتايج تجزيه واريانس صفات مرتبط با باززايى از ميانگره ينج رقم سيبزمينى در شرايط كشت درون شيشه

\begin{tabular}{|c|c|c|c|c|c|c|c|c|}
\hline \multicolumn{3}{|c|}{ اندازه اندام باززايى شده (سانتىمتر) } & \multicolumn{3}{|c|}{ تعداد اندام باززايى شيدين مربعات } & \multirow{2}{*}{ 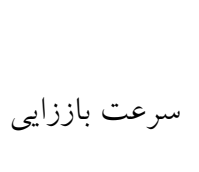 } & \multirow{2}{*}{ آزادى درجه } & \multirow{2}{*}{ منابع تغيير } \\
\hline طول جنين & طول ريشه & طول ساقه & جنين & ريشه & ساقه & & & \\
\hline $0 / 101^{* *}$ & $\circ / \% V^{n s}$ & $r / \circ T^{*}$ & $1 / 9 Y V^{* *}$ & $\circ / \circ \psi\rangle^{\mathrm{ns}}$ & $1 / Y 99^{* *}$ & $109 / 999^{* *}$ & i & رقم \\
\hline$\circ / \% Y Y^{\text {ns }}$ & $\circ / 099^{* *}$ & $\mid Y / \Lambda \circ r^{* *}$ & $\circ / 4 \subset \mathcal{Y}^{*}$ & $\circ / 19 Y^{* *}$ & $\circ / \Delta Q Y^{*}$ & $9 \Lambda / T T^{* *}$ & c & BAP \\
\hline $0 / 01 \mathrm{kns}^{\mathrm{ns}}$ & $\circ / \circ V^{n s}$ & $\Delta / V \circ q^{* *}$ & $\circ / \circ \wedge \xi^{n s}$ & $\circ / \circ Y_{\circ} \mathrm{ns}$ & o/DMK* & $9 / \mathrm{IV}^{\mathrm{ns}}$ & 0 & Kin \\
\hline 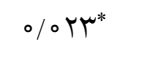 & $\circ / \nvdash^{\mathrm{ns}}$ & $1 /\left.49\right|^{* *}$ & $\circ / 19 V^{n s}$ & $\circ / \circ \Delta \mathcal{G}^{*}$ & $\circ / \uparrow \Delta V^{*}$ & 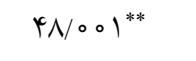 & 19 & ل \\
\hline$\circ / 0 \circ 9^{\mathrm{ns}}$ & $0 / 01 V^{n s}$ & $1 / \Lambda \Lambda \Lambda^{\mathrm{ns}}$ & $\circ / / \mu \Delta^{n s}$ & $\circ / 0 Y_{\circ} \mathrm{ns}$ & $\circ / T \wedge Y^{\mathrm{ns}}$ & $9 / 9 \circ y^{\text {nns }}$ & ro & رقم ×in \\
\hline $0 / 010$ ns & ०/० rqns & 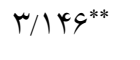 & $0 / / 4 Y^{n s}$ & . & $\circ / 4 \Delta^{\mathrm{ns}}$ & $r M / l \circ \Delta^{n s}$ & ro & $\mathrm{BAP} \times$ kin \\
\hline$\circ / \circ \circ q^{n s}$ & $0 / 019^{n s}$ & I/TGMns & $\circ / \| k^{\mathrm{ns}}$ & $\circ / 0 Y I^{\mathrm{ns}}$ & $\circ / Y Y V n s$ & $\mid Q / \backslash \wedge V^{n s}$ & $\Lambda_{0}$ & رقم × \\
\hline $0 / 011$ & $0 / 0 Y 9$ & $1 / \pi \wedge G$ & $\circ / \mathrm{VA}$ & O/OYT & $0 /$ TYG & 10/Ar。 & r。o & خطا \\
\hline $10 / 4$ & $r y / 1$ & $19 / 1$ & $9 / \mu$ & $\Lambda / 4$ & $\mathrm{IV} / \mathrm{T}$ & $11 / 0$ & (صد) & ضريب تغييرات ( \\
\hline
\end{tabular}

\begin{tabular}{|c|c|c|c|c|c|c|c|}
\hline \multicolumn{3}{|c|}{ اندازه اندام باززايى شده (سانتى متر) } & \multicolumn{3}{|c|}{ تعداد اندام باززايى شده } & \multirow{2}{*}{ سرعت باززايى } & \multirow{2}{*}{ 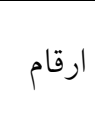 } \\
\hline طول جنين & طول ريشه & طول ساقه & جنين & 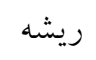 & 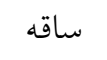 & & \\
\hline $1 / D Y^{c}$ & $1 / 0 \circ^{a}$ & $1 / \wedge \Delta^{b}$ & $1 / 91^{b}$ & $1 / \Delta \varphi^{a}$ & $r /\left.\circ\right|^{a}$ & $\Delta / r^{b}$ & آريندا \\
\hline $1 / \Delta Y^{b c}$ & $1 / 0 r^{\mathrm{ca}}$ & r/ra & $1 / N^{w b}$ & $1 / 0 \circ \mathrm{a}$ & $1 / N^{\mathrm{wb}}$ & $\varphi / \circ \Delta^{c}$ & 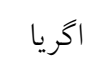 \\
\hline $1 / \Delta V^{a b}$ & l/Q & $1 / 9 \mu^{b}$ & $1 / N \circ b$ & $1 / \Delta r^{a}$ & $1 / \Lambda \Lambda^{\mathrm{ab}}$ & $r / \mu q b$ & 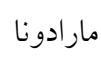 \\
\hline$|/ 9|^{\mathrm{a}}$ & $1 / 01^{\mathrm{a}}$ & $r / \circ q^{a b}$ & $1 / 99^{a}$ & $1 / \Delta \mu^{\mathrm{a}}$ & $1 / V \wedge^{b}$ & $4 / V \wedge^{\mathrm{a}}$ & 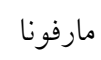 \\
\hline $1 / \Delta r b c$ & l/هra & $Y / \circ Y^{a b}$ & $1 / 9 \mathrm{~V}^{\mathrm{b}}$ & $1 /\left.\Delta\right|^{r a}$ & $1 / \mu^{\mathrm{b}}$ & $\Gamma / \mu, c$ & سانته \\
\hline
\end{tabular}

ميانگينهايى كه داراى حداقل يك حرف مشابه باشند، براساس آزمون دانكن تفاوت معنىدارى در سطح احتمال ينج درصد ندارند.

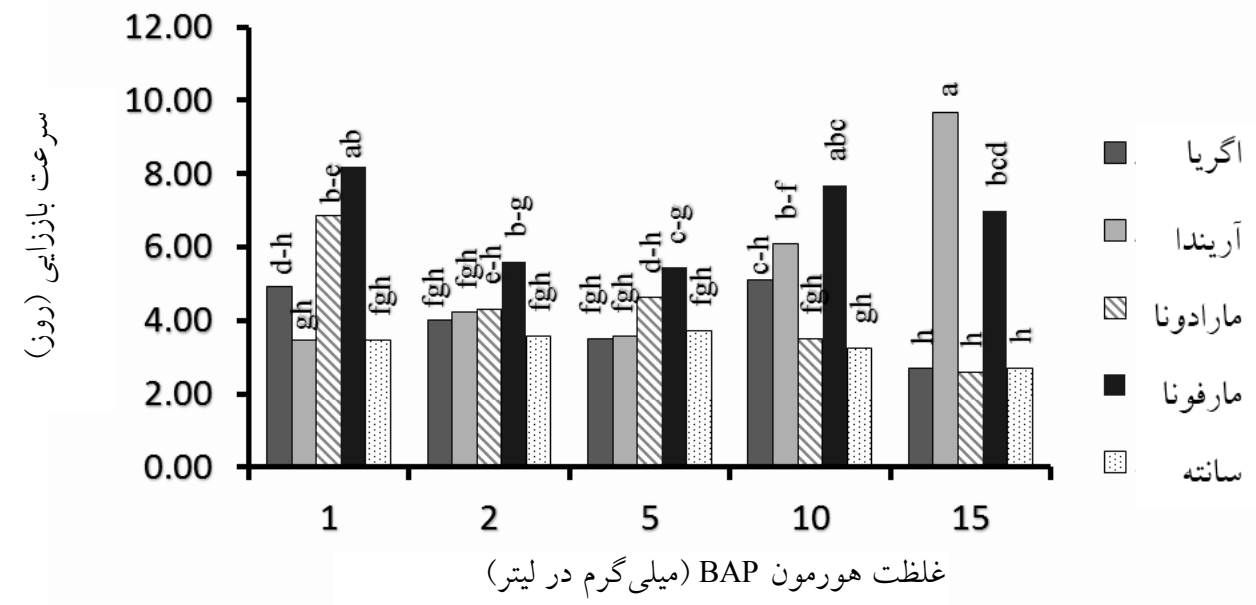

شكل 1. مقايسه ميانگين سرعت باززايى در سطوح مختلف هورمون BAP و رقم. ميانخينهايى كه داراى حداقل يك حرف مشترك باشند،

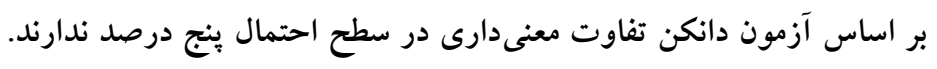


جدول ب. نتايج مقايسه ميانگين صفات مورد بررسى در غلظتهاى مختلف تنظيم كنندهاى BAP و Kin

\begin{tabular}{|c|c|c|c|c|c|c|c|c|}
\hline \multicolumn{3}{|c|}{ اندازه اندام باززايى شده (سانتى متر) } & \multicolumn{3}{|c|}{ تعداد اندام باززايى شده } & \multirow{2}{*}{\multicolumn{2}{|c|}{ 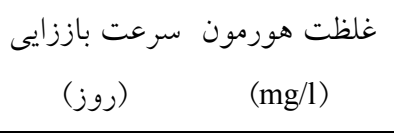 }} & \multirow{2}{*}{ 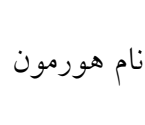 } \\
\hline طول جنين & 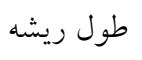 & طول ساقه & جنين & 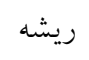 & 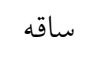 & & & \\
\hline $1 / 0 V^{a}$ & $1 / 0 \mathrm{~V}^{\mathrm{a}}$ & Y/qYa & $1 / N Y^{\mathrm{ab}}$ & $1 / 09^{a}$ & $1 / 9 \Delta^{a}$ & $\varphi / \mu \wedge^{b}$ & 1 & \\
\hline $1 / \Delta y^{c a}$ & $1 / \partial{ }^{c a b}$ & $r / T V^{\mathrm{ab}}$ & $1 / g^{\mathrm{b}}$ & $1 / \Delta \varphi^{a}$ & $1 / \wedge \Delta^{a b}$ & $\varphi / \sim \Delta^{b}$ & r & \\
\hline $1 / \Delta \wedge^{\mathrm{a}}$ & $1 / 0 \circ b$ & $1 / 9 r^{b c}$ & l/Aץa & $1 / 0 \circ b$ & $1 / N q^{b}$ & $\varphi / l V^{b}$ & $\Delta$ & BAP \\
\hline $1 / \Delta \Delta^{\mathrm{a}}$ & $1 / 0 \circ b$ & $1 / \mathrm{V} V^{\mathrm{c}}$ & $1 / \mathrm{V} V^{\mathrm{ab}}$ & $1 / 0 \circ b$ & $I / V \wedge^{b}$ & $ه / / \mu^{a}$ & 10 & \\
\hline $1 / 0 t^{c a}$ & $1 / 0 \circ b$ & $1 / 9 Y^{\mathrm{c}}$ & $1 / \mathrm{V}^{\mathrm{a}} \mathrm{a}$ & $1 / 0 \circ b$ & I/NGb & $\varphi / q q^{\mathrm{ab}}$ & 10 & \\
\hline $1 / \Delta \varphi^{a}$ & $1 / \Delta Y^{a}$ & $\Gamma / \Upsilon^{\mu} \Lambda^{\mathrm{a}}$ & $\mid / V Y^{c a}$ & $1 /\left.\Delta\right|^{c a}$ & $1 / 91^{a}$ & $Y / V)^{a}$ & $\circ / 0$ & \\
\hline $1 / \Delta \Delta^{a}$ & $1 / \Delta Y^{c a}$ & $r / \circ V^{a b}$ & $1 / V^{\circ} a$ & $1 / \Delta \mu^{a}$ & $1 / \Lambda c^{c a b}$ & $\varphi / \wedge q^{a}$ & 1 & \\
\hline $1 / \Delta \wedge^{\mathrm{a}}$ & $1 / \Delta \Delta^{\mathrm{a}}$ & $1 / 9 \mu^{b}$ & $1 / \Lambda \circ a$ & $1 / \Delta \Delta^{a}$ & $1 / V q^{a b}$ & $ه / \circ \wedge^{\mathrm{a}}$ & r & \\
\hline $1 / \Delta \varphi^{a}$ & $1 /\left.0\right|^{a}$ & r/YYaa & $1 / V{ }^{q a}$ & $1 / \Delta r^{a}$ & l/94a & $Q / \circ \varphi^{\mathrm{a} a}$ & 0 & Kin \\
\hline $1 / \Delta r^{\mathrm{a}}$ & $1 / 0 \circ a$ & $1 / \mathrm{N}^{\mathrm{m}} \mathrm{b}$ & $1 / V 1^{a}$ & $1 /\left.0\right|^{a}$ & $1 / \mathrm{V} \wedge^{\mathrm{ab}}$ & $\varphi / V \varphi^{a}$ & 10 & \\
\hline $1 / \Delta \varphi^{a}$ & $1 /\left.0\right|^{a}$ & $1 / \Lambda \circ b$ & $1 / V Y^{a}$ & $1 / \Delta \mu^{a}$ & $1 /\left.N\right|^{b}$ & $\mathcal{\varphi} / Y \wedge^{\mathrm{a}}$ & 10 & \\
\hline
\end{tabular}

ميانخين هايى كه داراى حداقل يك حرف مشابه باشند، بر اساس آزمون دانكن تفاوت معنى دارى در سطح احتمال پينج درصد ندارند.

شده نشاندهنده وجود تفاوت بسيار معنىدارى در بين ارقـام از نظر ساقهزايى و جنينزايى بـود. رقـم آرينــا بيشـترين توانـايى ساقهزايى و رقم مارفونا بيشترين توانايى جنينزايى را بـه خــود اختصاص دادند. در بين ساير ارقام تفـاوت قابـل ملاحظـهاى از نظـر سـاقهزايسى و جنـينزايسى وجـود نداشـتــ از نظـر ميـزان ريشهزايى تفاوت معنى دارى در بين ارقام مشاهده نشد (جـدول او Y). تجزيه واريانس اثرات ساده هورمونهـاى BAP و Kin و اثر متقابل هورمون BAP با رقـم در بـاززايى سـاقه در سـطح احتمال ينج درصد معنى دار بود، اما اثر متقابل رقـم بـا هورمـون Kin تجزيه واريانس دادههاى مربوط به ايسن صـفت، هورمسون BAP بيشترين تأثير را بر بـاززايى ريشـه داشـته اسـت كـه در سـطح احتمال يك درصد بسيار معنى دار بــوده اسـت و هورمسون Kin تأثير معنى دارى بر باززايى ريشه در هيج يـك از سـطوح نشـان نداد. بررسى اثر متقابل هورمون BAP و رقم حاكى از معنسىدار شدن اين عامل در سطح احتمال ينج درصد بـر بـاززايى ريشـه

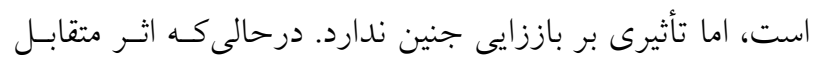

تفاوت بين ارقام از نظـر سـرعت بــاززايى در تعــاد زيـادى از

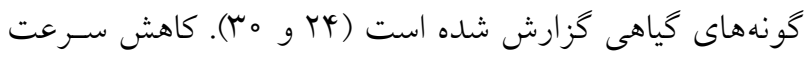

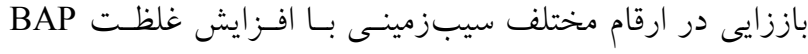

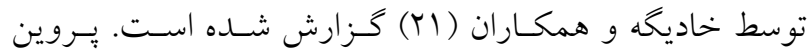
(TV)

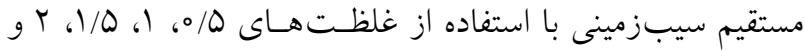
r/D ميلى گرم در ليتر هورمونها، بيشترين سرعت بـاززايى را در

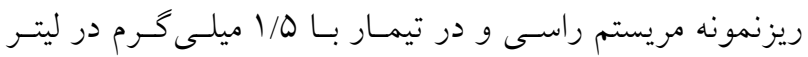
هورمسون BAP بـهدسـت آورد و هورمسون BAP را مسؤثرتر از هورمون Kin در سرعت باززايى دانسـت. همجنــين در بررسى اثرات متقابل هورمونها با ارقام در ريزنمونسهـهـاى مختلـف اثـر معنى دارى بر سرعت باززايى مشاهده نكرد. شهريار و همكـاران

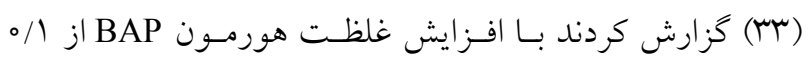
ميلى گرم در ليتر به ب/ه ميلى گـرم در ليتـر سـرعت بـاززايى در ريزنمونه هاى مختلف سيبزمينى افزايش مى يابد. نوع اندام باززايى شده تجزيه واريانس دادههاى بهدست آمده براى نـوع انــام بـاززايى سي 


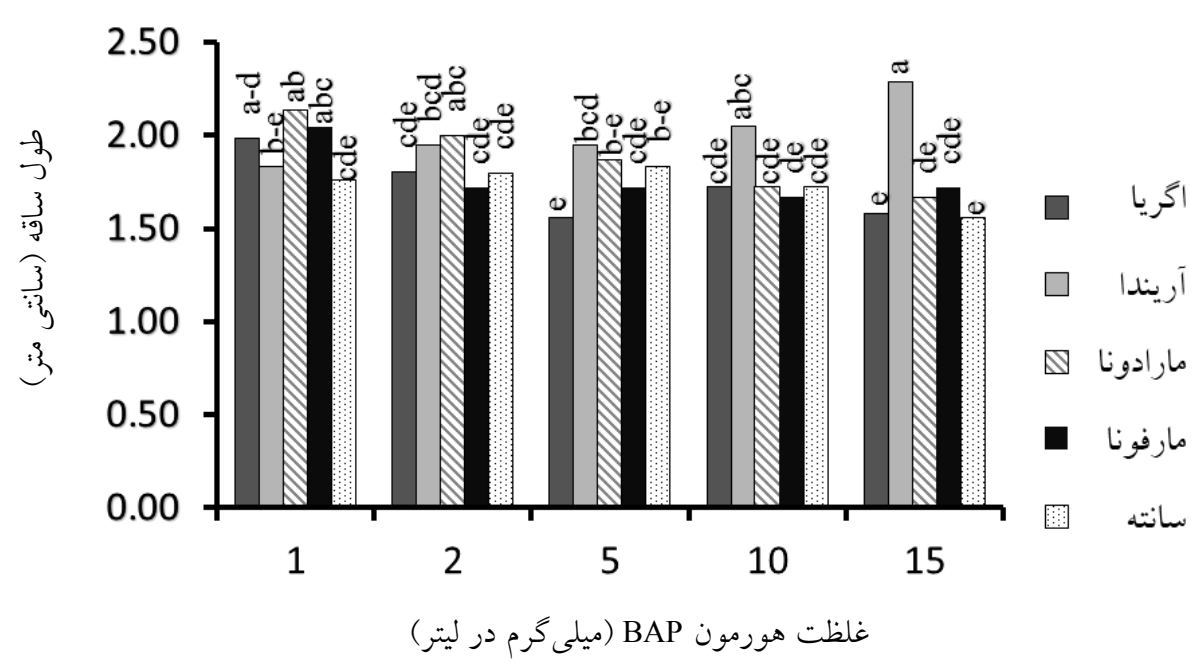

شكل r. مقايسه ميانكين تعداد ساقه در سطوح مختلف هورمون BAP و رقم. ميانگينهايى كه داراى حداقل يك حرف مشتر بـ باشند، بر اساس آزمون دانكن تفاوت معنىدارى در سطح احتمال ينج درصد ندون ندارند.

بـهدسـت آوردنســ. بـادونى و جاهــان (9) در بررسـى تـأثير

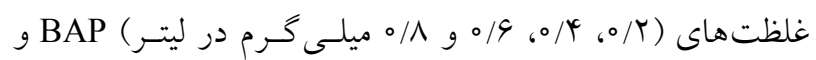
Kin هورمون شاخه و در غلظتهاى پاييين تر فقط كـالوس بـهدست

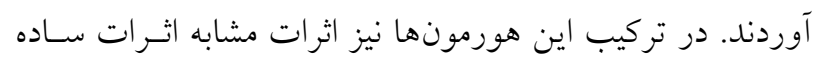
بهدست آوردند. على و همكاران (r) در جنينزايى غير مستقيم نيشكر در ريزنمونهاى مختلف در غلظـت يـايين BAP جنسين

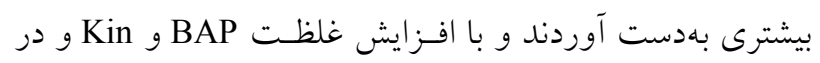
اثر متقابلشان جنينزايى كمترى مشاهده كردند. در كتـان تعـداد

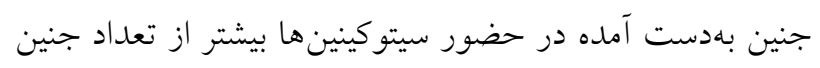

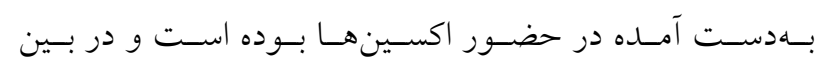

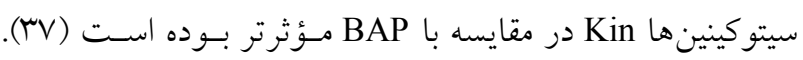
هوكيو (19) با افزايش غلظت هورمون Kin در سرعت بـاززايى، تعداد شاخه توليدى و طول شاخههاى توليد شده در سيبزمينى

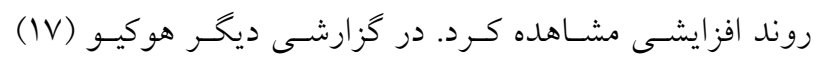

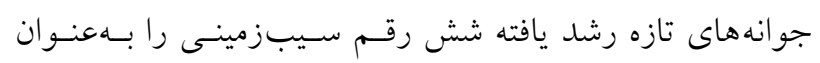

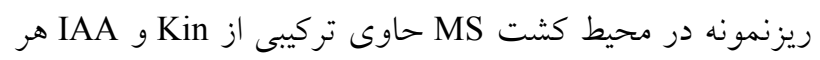

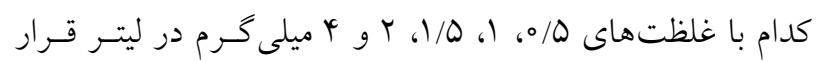
داده، كه در بين تيمارهاى مختلف، در تركيـب دو ميلـى كـرم در

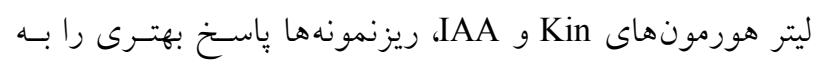

هورمون Kin با رقم تأثير معنىدارى بر ريشهزايى و جنسينزايس (حائ

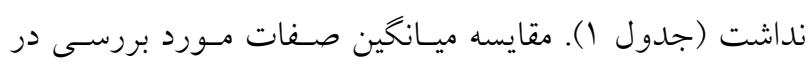

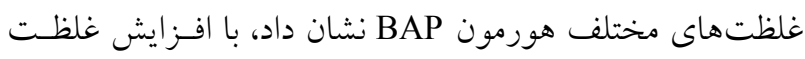
اين هورمون ميـزان بـاززايى سـاقه و ريشـهـ كـاهش امـا ميـزان

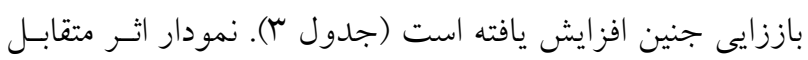

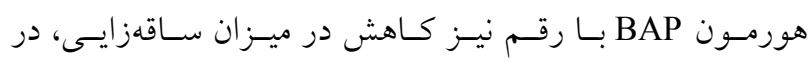

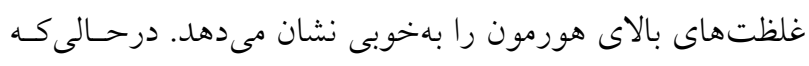

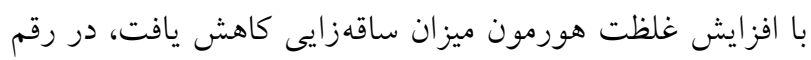

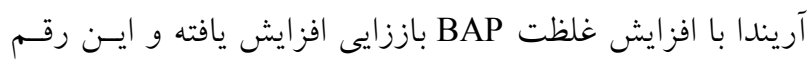

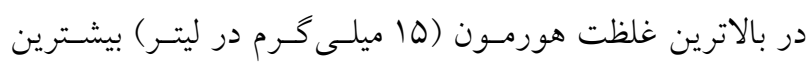

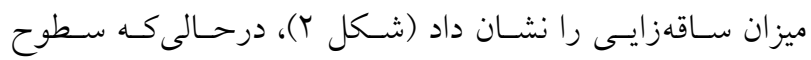
مختلف هورمون BAP تأثير معنى دارى در سـطح احتمـال يـنج درصد نسبت به جنين زايى نشان دادند، سطوح مختلف هورمون تأثير معنى دارى بر جنسينزايسى نداشـتند. مقايسـه ميـانكين صفات مورد بررسى در غلظتهاى مختلف هورمون BAP نشان

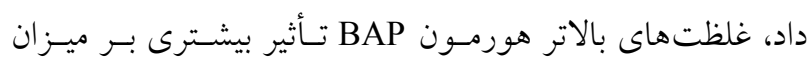

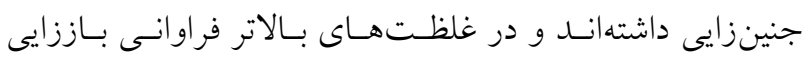

$$
\text { جنين ها بيشتر بود (جدول م) (r). }
$$

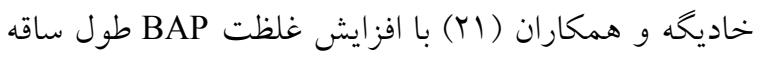

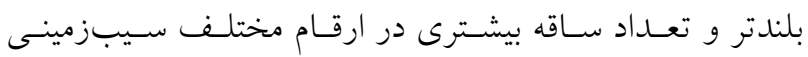


مin ميانكين صفات مورد بررسى در غلظتهاى مختلف هورمون

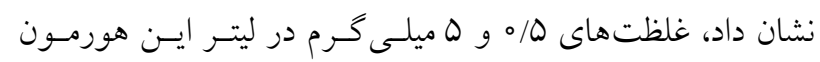

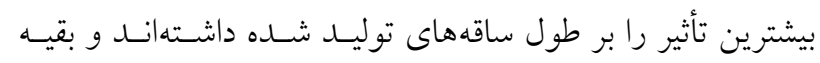

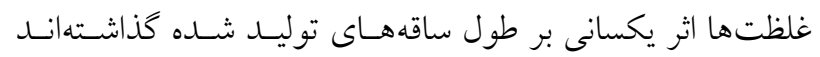
(جدول r). تجزيه واريانس دادهها در مورد طول ريشـهــا توليـد در تيمارهاى مختلف نشان داد بهجز اثرات سـاده هورمسون BAP

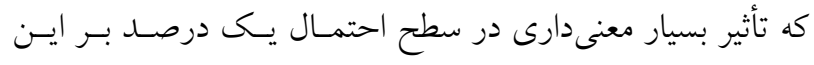

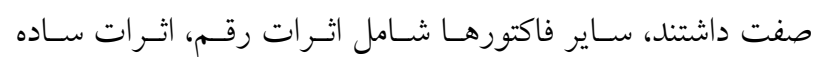

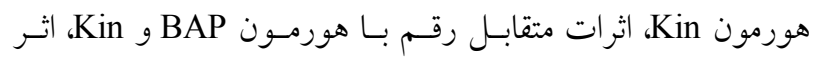

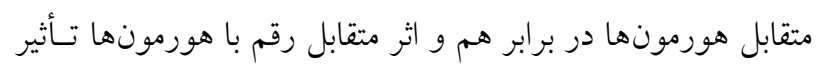

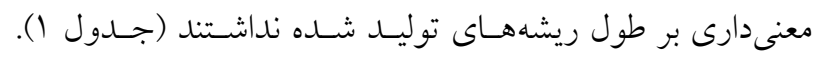

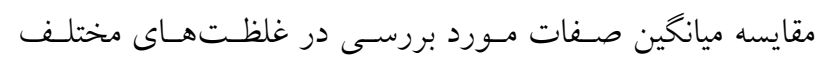

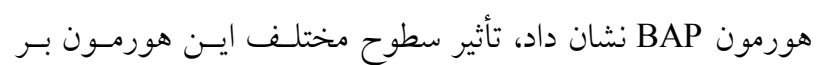

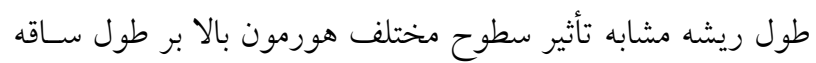

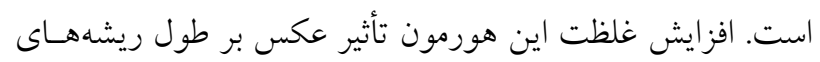

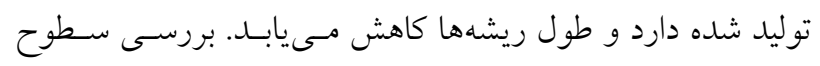

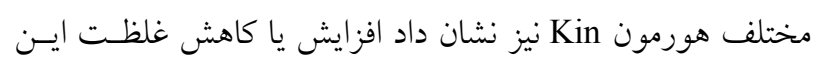

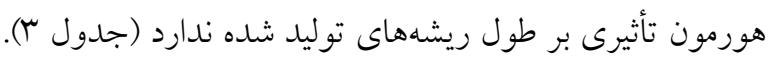

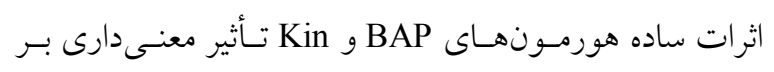

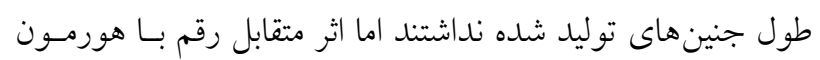

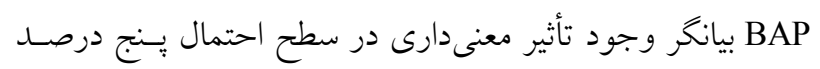

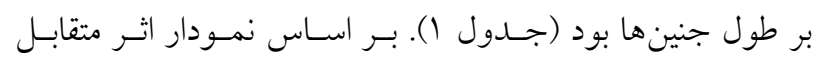
هورمون BAP و رقم بر اندازه جنين هاى توليد شده، رقم مارفونـا

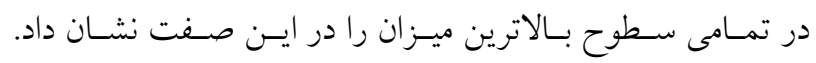

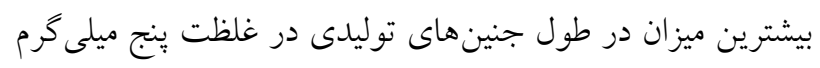

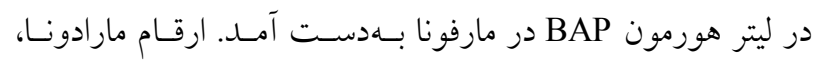

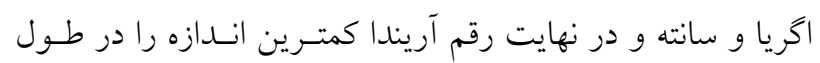

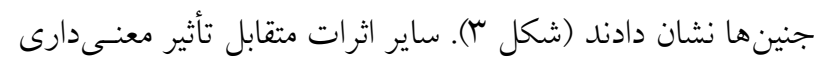

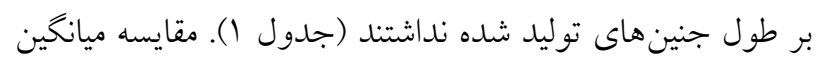

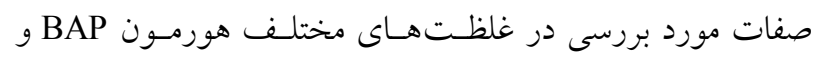
هورمون Kin نشان داد، سطوح مختلف اين هورمونها تأثيرى بـر مورد طول جنينهاى توليد شده نداشته است (جدول Y و ؟r).
ساقهدهى و ريشهدهى نشان دادند و سرعت باززايى بيشترى نيز

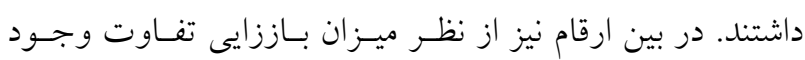
داشت. اثر متقابل بين غلظتهــاى هورمـونى و ارقـام در سـطح احتمال ينج درصد نيز معنىدار گزارش شد. شهريار و همكـاران

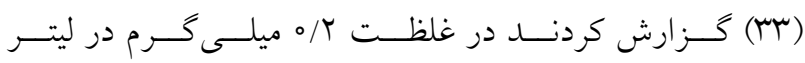
هورمونBAP ساقهزايى بيشترى مشاهده كردند.

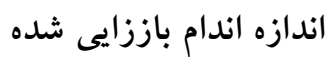

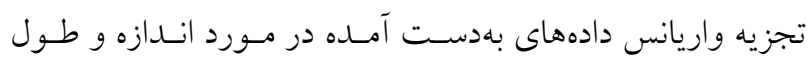

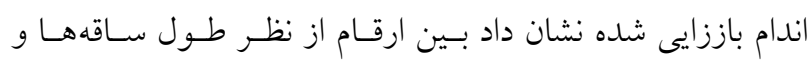
جنينهاى توليدى بهترتيب تفاوت معنسى دارى در سـطح احتمـال

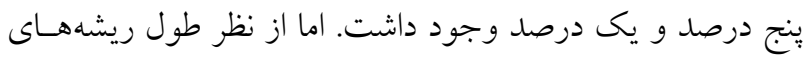
توليد شده بين ارقام، اختلاف معنى دارى مشاهده نشد (جدول ().

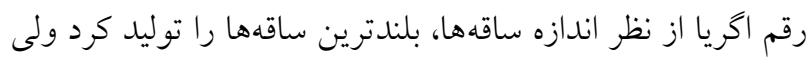

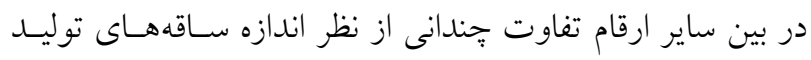
شده وجود نداشت. از نظر اندازه جنين هاى توليدى، رقم مارفونـا

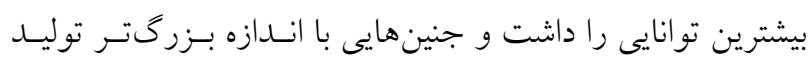

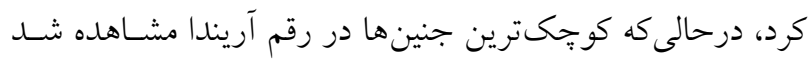

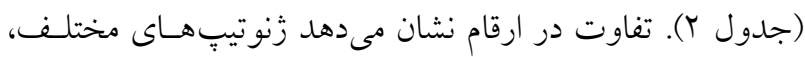
تأثيريذيرى متفاوتى از شرايط درون شيشهاى دارند. نتـايج تجزيـهـ

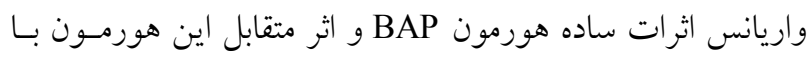

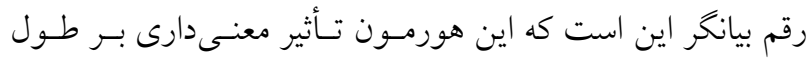

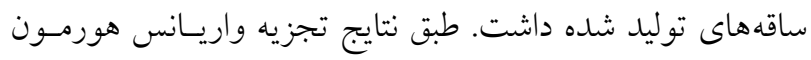

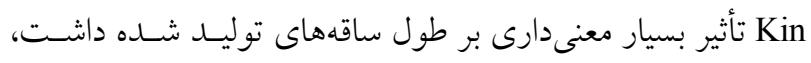

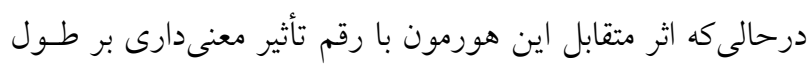

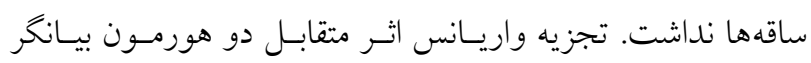

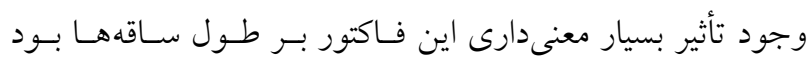

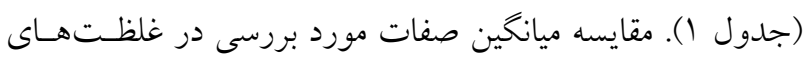
مختلف هورمون BAP نشان داد، افـزيش غلظـت ايسن هورمـون

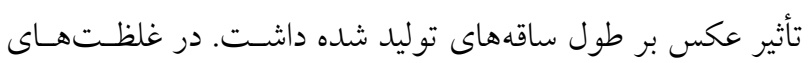

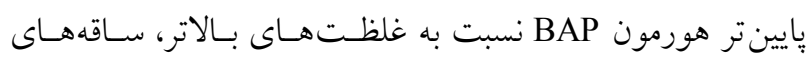

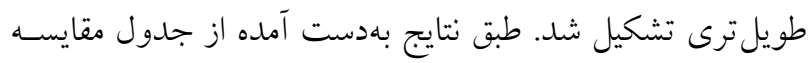




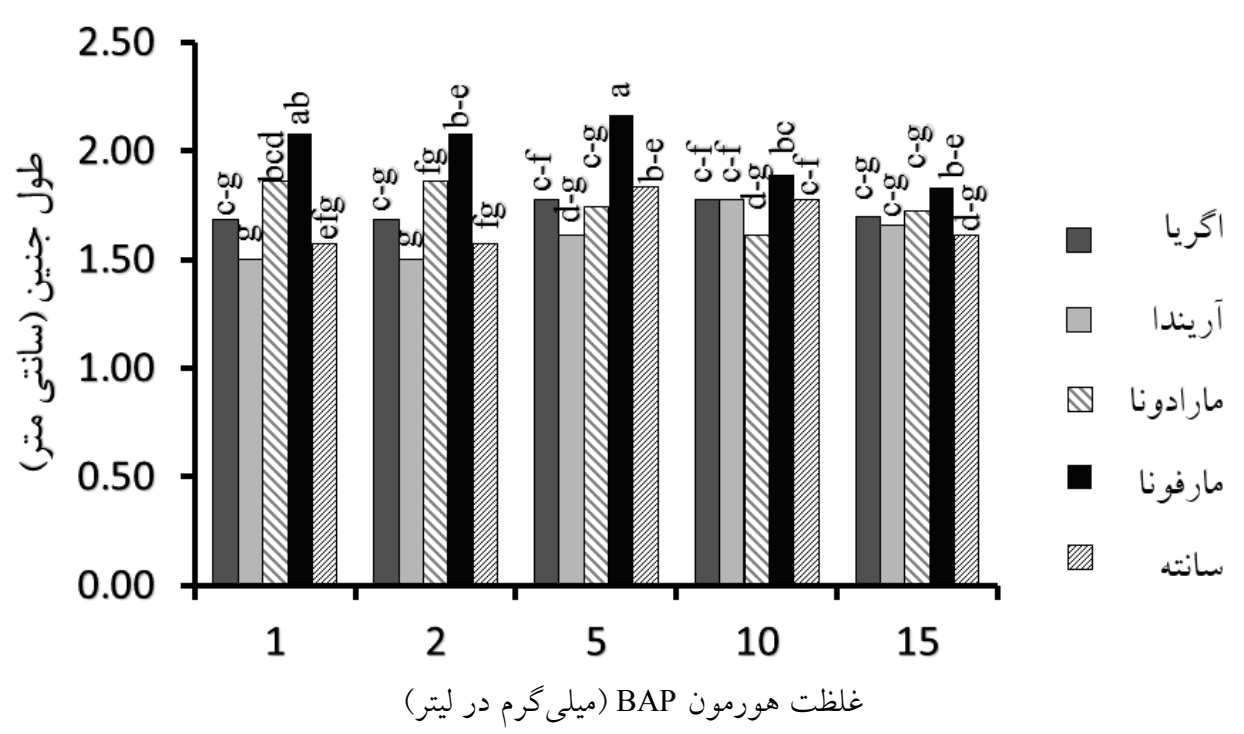

شكل r. مقايسه ميانگين طول جنين در سطوح مختلف هورمون BAP و رقم. ميانگينهايى كه داراى حداقل يك حرف مشترك باشند، بر

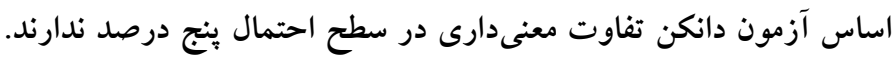

باززايى شده و اندازه انـدام بـاززايى شـده وجـود دارد. در بسين

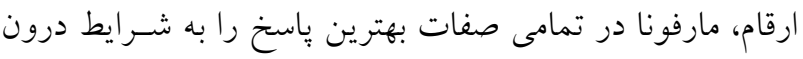

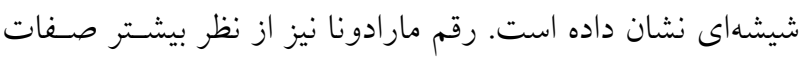

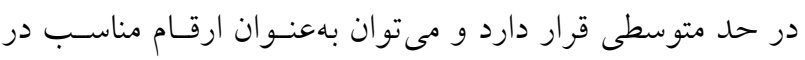

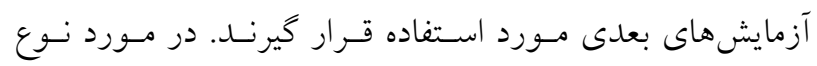

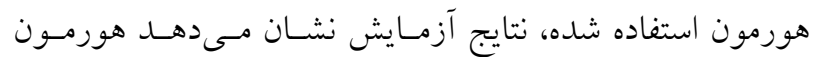

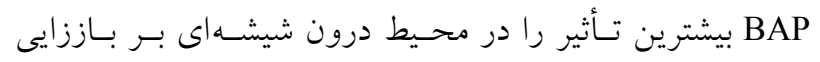

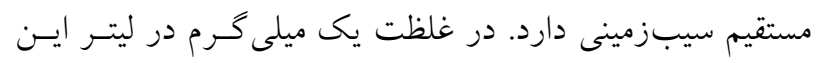

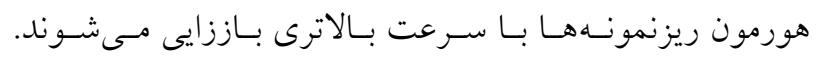

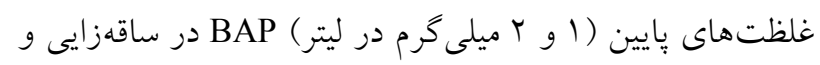

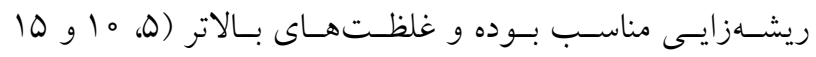

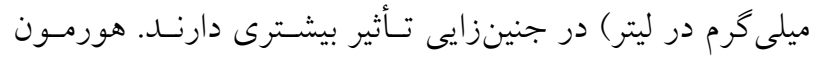
Kin

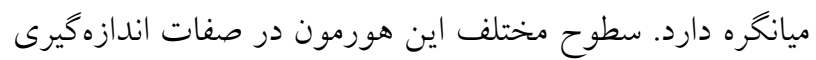

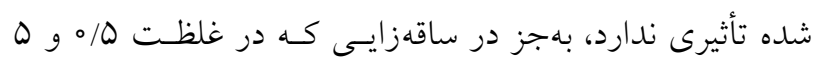

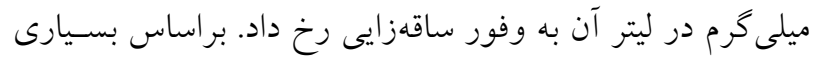

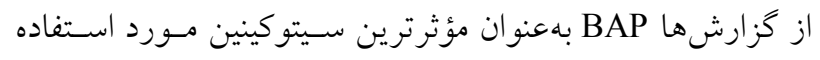

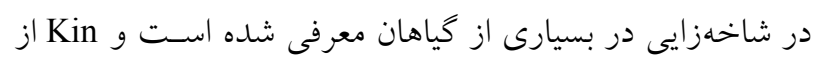

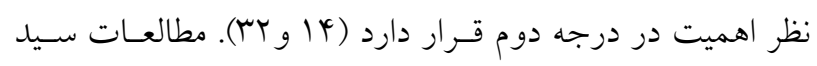

تفاوت معنى دار در بين ارقام مختلف سيبزمينى در طول انـدام

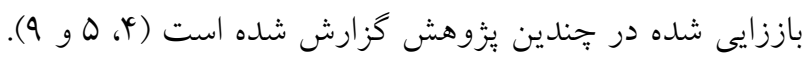

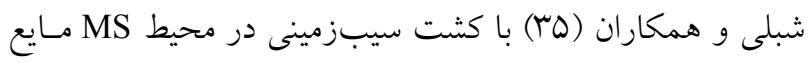

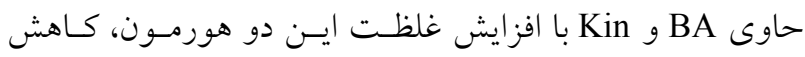

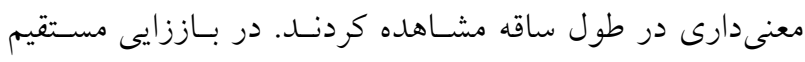

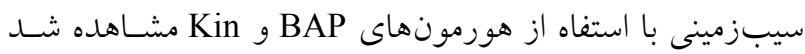
در غلظتهاى بايين هورمونها اندازه اندام باززايى شـــه بيشـتر

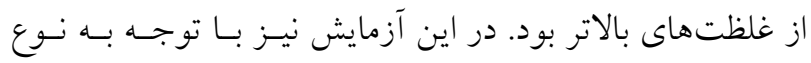

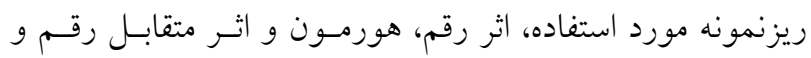

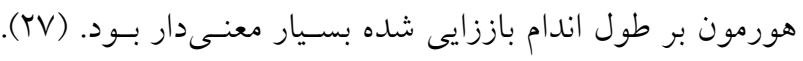

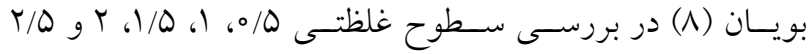
ميلى گرم در ليتر هورمسونهـاى BAP و Kin بــر بـاززايى ارقـام

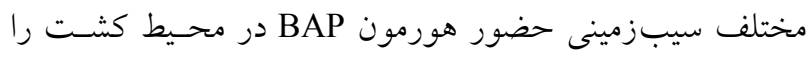

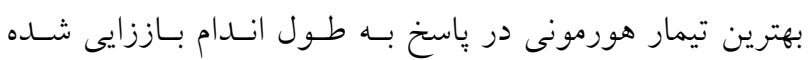

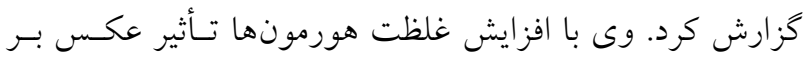
طول اندام باززايى شده مشاهده كرد.

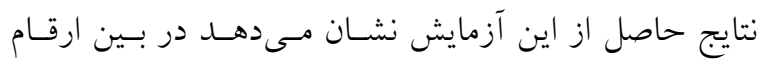
مختلف سيبزمينى اختلاف بسيار معنىدارى از نظر كليه صفات

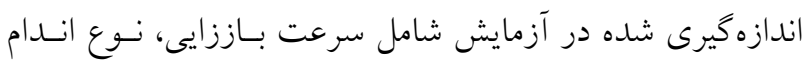


تحقيق فقط به بررسى نقش سيتوكنينها در توليد اندام يرداختـه شد و نشان داده شد كه استفاده از سيتوكنينها بهتنهايى مىتواند در ريشهزايى، جنينزايى و ساقهزايى موثر باشد كه البته در ايسن خصوص نقش تنظيم كنــده BAP از Kin بيشـتر بـود بـا ايسن وجود بيشترين تأثير سيتوكنينها همانطور كه انتظار مىرفت بر توليد ساقه و جنين بود تا توليد ريشـه. سـيتوكنينهـاى اسـتفاده شده در اين تحقيق نقش مؤثرى در افزايش طول اندام القاء شده هم داشتند (بهخصوص BAP) كه اين موضوع مىتواند بـهدليـل نقش سيتوكنينها در افزايش تقسيم سلولى باشد نه طويل شـدن سلولها. تأثير سيتوكنينها در كشت بافت يا اندام براساس نوع تركيـبـ استفاده شده، نوع كشت، نوع كياه و سن ريز نمونه متفاوت اسـت

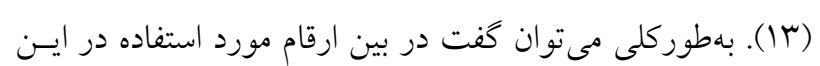

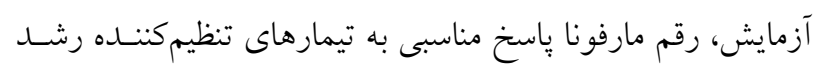

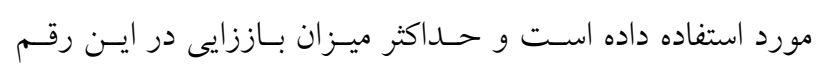

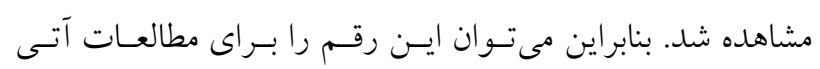
بيشنهاد كرد. تنظيمكنتده BAP نيز بيشترين مقدار باززايى مستقيم

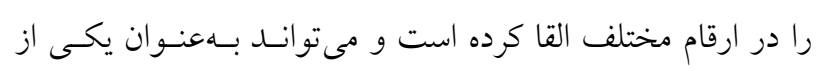
تنظيم كنندهاى اصلى در مطالعات مربوط به باززايى سـيبزمينى در شرايط درون شيشه استفاده شود.

طباطبايى و اميدى (rr) نشان داده است كه غلظتى از BAP كـهـ براى شاخهزايى بهكار مىرود اغلب بـين ا تـا ها ميكرومـولار است. در حالى كه غلظت مناسب براى شاخهزايسى در Kin بـين ه r تا •ه ميكرومولار است. اين تفاوت دامنه غلظتهــا قـدرت بيشتر BAP براى شاخهزايى را نشان مىدهد.

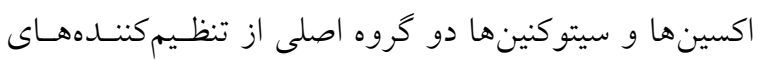
رشد هستند كه بهوفور در كشت بافت گياهان مورد استفاده قرار

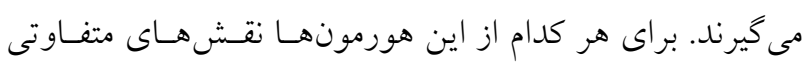
ذكر شده است اما مكانيسم عمل مشابهى هم براى آنها ذكر شده است كه از جمله آن مىتوان به دخالت در تقسيم سلولى و نيـز القاى اندامزايى اشاره كرد. اكسينهـا معمـولاً در ريشـهزايسى و سيتوكنينها در ساقهزايى و جنينزايى مؤثر هستند. تعيين نسبت اين دو نوع تنظيمكننده در توليد نوع اندام ايجاد شده مهم اسـت اما در برخى از گياهان استفاده از فقط يكى از اين تنظيمكنندها

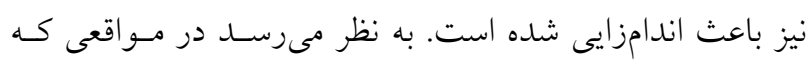
هدف القاى اندامزايى مستقيم از بافت گياهى باشد، با توجـهـ بـهـ اينكه در خود بافتهاى كشت شده مقدارى هورمون داخلى نيز

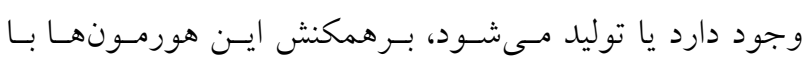

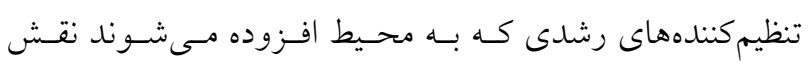
اساسى در اندامزايى ايفا مىكند (rا). بـه همسين دليـل در ايسن

منابع مورد استفاده

1. Ahmad, M. Z., I. Hussain, S. Roomi, M. A. Zia, M. SH. Zaman, Z. Abbas and S. H. Shah. 2012. In vitro response of cytokinin and auxin to multiple shoot regeneration in Solanum tuberosum L. American-Eurasian Journal of Agricultural and Environmental Sciences 12(11): 1522-1526.

2. AL-Hussaini, Z. A, SH. A. Yousif and S. A AL-Ajeely. 2015. Effect of different medium on callus induction and regeneration in Potato cultivars. Internatinol Journal of Current Microbiology and Applied Sciencs 4(5): 856-865

3. Ali, A., SH. Naz and J. Iqbal. 2007. Effect of different explants and media compositions for efficient somatic embryogenesis in sugarcane (Saccaharum officinarum). Pakistan Journal of Botany 39(6): 1961-1977.

4. Al-Taleb, M. M., D. S. Hassawi and S. M. Abu-Romman. 2011. Production of virus free potato plants using meristem culture from cultivars grown under Jordanian environment. American-Eurasian Journal of Agricultural and Environmental Sciences 11(4): 467-472.

5. Andreea, N., GH. Campeanu, N. Chiru and D. Karacsonyi. 2009. Effect of auxine and cytokinine on callus induction in potato (Solanum tuberosym L.) explants. Agricultura- Stiinta si Practica 1-2(69-70): 47-50.

6. Badoni, A. and J. S. Chauhan. 2009. Single node callus culture: improvement for micropropagation of Solanum tuberosum (cv. Kufri Himalini). Nature and Science 7(3): 99-103.

7. Bakul, S. A. 2005. In vitro culture of Potato (Solanum tuberosum L.): callus induction, plantlet regeneration and microtuberisation. MSc. Thesis, Bangladesh Agricultural University, Memensingh, Bangladesh.

8. Bhuiyan, F. R. 2013. In vitro meristem culture and regeneration of three potato varieties of Bangladesh. Research in Biotechnology 4(3): 29-37. 
9. Chakravarty, B. and G. Wang-Pruski. 2010. Rapid regeneration of stable transformants in cultures of potato by improving factors influencing Agrobacterium-mediated transformation. Advances in Bioscience and Biotechnology 1: 409-416.

10. Corrêa Ricardo, M., E. José, B. P. Pinto, F.Valdemar, B. P. César Augusto Pinto and S. R. Erika. 2009. The production of seed potatoes by hydroponic methods in Brazil. Fruit Vegetable and Cereal Science and Biotechnology 3(Special Issue1): 133-139.

11. Danin, M., S. J. Upfold, N. Levin, B. L. Nadel, A. Altman and J. Van Staden. 1993. Polyamines and cytokinins in celery embryogenic cell cultures. Plant Growth Regulation 12(3): 245-254.

12. Dhital, SH. P., H. T. Lim and H. K. Manandhar. 2011. Direct and efficient plant regeneration from different explants sources of potato cultivars as influenced by plant growth regulators. Nepal Journal of Science and Technology 12:1-6

13. Edwin, F. G., A. H. Micheal and D. K. Geert-Jan. 2008. Plant Propagation by Tissue Culture. $3^{\text {rd }}$ ed. Springer, Netherland.

14. Farsi, d. and J. Zolala. 2003. Principles of Plant Biotechnology. University of Mashhad, Mashhad, Iran.

15. Ghahreman, A. 1994. Flore of Iran (Plant Systematics), University Publishing Center, Tehran, Iran.

16. Hoque, M. E. 2010. In vitro tuberization in potato (Solanum tuberosum L.). Plant Omics Journal 3(1): 7-11.

17. Hoque M. E. 2010. In vitro regeneration potentiality of potato under different hormonal combination. World Journal of Agricultural Sciences 6(6): 660-663.

18. Hossain, M. A., M. Shamimuzzaman, M. A. Haque, A. U. Haque, and M. D. Hossain. 2009. Regeneration of potato varieties from internode slices using zeatin riboside. International Journal of Sustainable Agricultural Technology 5(4): 6-11.

19. Jayasree, T., U. Pavan, M. Ramesh, A. V. Rao, K. M. Reddy and A. Sadanandam. 2001. Somatic embryogenesis from leaf culture of potato. Plant Cell Tissue Organ Culture 64(1): 13-17.

20. Kaur, M., R. Kaur, C. Sharma, N. Kaur and A. Kaur. 2014. Effect of growth regulators on micro propagation of potato cultivars. Journal of Cell and Tissue Research 14(1): 4363-4366.

21. Khadiga, G. A. E., S. M. Rasheid and M. M. Khalafalla. 2009. Effect of plant growth regulators on callus induction and plant regeneration in tuber segment culture of potato (Solanum tuberosum L.) cultivar Diamant. African Journal of Biotechnology 8(11): 2529-2534.

22. Linden, L. and A. Riikonen. 2006. Effect of 6-benzyleaminopurin, thidiazuron and type of explant on in vitro shoot development of Acer platanoides L. Propagation of Ornamental Plants 6(4): 201-204.

23. Magyar-Ta'bori, K., J. Dobra'nszki, J. A. da Teixeira Silva, S. M. Bulley and k. I. Huda'. 2010. The role of cytokinins in shoot organogenesis in apple. Plant Cell, Tissue and Organ Culture 101(3): 251-267.

24. Maleki Band, S., M. Jafari, M. Ghadimizadeh and I. Bernousi. 2013. Plant regeneration via direct organogenesis in three Alfalfa (Medicago sativa L.) cultivars using stem nodal explant. Seed and Plant Improvment Journal 29(1): 65-80. (In persion)

25. Molla, M. M. H., K. M. Nasiruddin, M. Al-Amin, A. S. M. M. R. Khan and M. A. Salam. 2011. Effect of 6benzylaminoourin, thidiazuron and zeatin riboside on direct regeneration of potato. South Asian Association for Regional Cooperation Journal of Agriculture 9(1): 55-68.

26. Müller, B. and J. Sheen. 2007. Advances in cytokinin signaling. Science 318(5784): 68-69.

27. Parveen, F. 2011. In vitro regeneration of three local potato (Solanum tuberosum L.) varieties of Bangladesh. MSc Thesis, BRAC University, Bangladesh.

28. Pernisová, M., P. Klíma, J. Horák, M. Válková, J. Malbeck, P. Soucek, P. Reichman, K. Hoyerová, J. Dubova, J. Friml, E. Zazímalova and J. Hejátko. 2009. Cytokinins modulate auxin-induced organogenesis in plants via regulation of the auxin efflux. Proceedings of the National Academy of Sciences of the United States of America 106(9): 3609-3614.

29. Peyman, M., M. R. Ghannadha, S. Majidi, A. J. Zarbakhsh, F. Darvish and H. Hasanabadi. 2004. Identification and introduction of Virus resistat genotypes in potato. Iranian Journal of Agriculture Science 35(4): 809-815. (In Farsi).

30. Sanatombi, K. and G. J. Sharma. 2008. In vitro plant regeneration in six cultivars of Capsicum spp. using different explants. Biologia Plantrum 52(1): 141-145.

31. Sarwar, M. and R. M. Skirvin. 1997. Effect of thidiazuron and 6-benzylaminopurine on adventitious shoot regeneration from leaves of three strains of 'McIntosh' apple (Malus X domestica Borkh.) in vitro. Scientia Horticulturae 68(1-4): 95-100.

32. Sayed-Tabatabaei, B. and M. Omidi. 2011. Plant cell and tissue culture. Tehran University Press, Tehran, Iran.

33. Shahriyar, S., S. Akram, K. Khan, M. Faruk Miya and M. Abdur Rauf Sarkar. 2015. In vitro plant regeneration of potato (Solanum tuberosum L.) at the rate of different hormonal concentration. Asian Journal of Medical and Biological Research 1(2): 297-303.

34. Sherkar, H. D. and A. M. Chavan. 2014. Effect of 2, 4-D; BAP and TDZ on callus induction and shoot regeneration in Potato. Science Research Reporter 4(1): 101-105. 
35. Shibli, R. A., A. M. Abu-Ein and M. M. Ajlouni. 2002. In vito and In vivo multiplication of virus-free Spunta potato clone. Pakistan Journal of Agricultural Research 17(1): 71-75.

36. Werner, T., V. Motyka, M. Strand and T. Schmülling. 2001. Regulation of plant growth by cytokinin. Proceedings of the National Academy of Sciences of the United State of America 98(18): 10487-10492.

37.Zhang, B., Q. Wang, F. Liu, K. Wang and T. P. Frazier. 2009. Highly efficient plant regeneration through somatic embryogenesis in 20 elite commercial cotton (Gossypium hirsutum L.) cultivars. Plant Omics Journal 2(6): 259-268. 


\title{
Effect of Cytokinins on Direct Regeneration of Five Potato Cultivars
}

\author{
B. Rahimian ${ }^{1}$, M. Rabiei ${ }^{\star *}$ and M. Khodambashi ${ }^{3}$
}

(Received: September 14-2017 ; Accepted: April 16-2018)

\begin{abstract}
In order to optimize direct regeneration of potato cultivars (Solanum tuberosum L.) including Arinda, Agria, Sante, Maradona and Marfona, a factorial experiment was carried out in the form of completely randomized design with three replications. Internode explants were placed on MS medium supplemented with different concentrations of 6Benzylaminopurine (1, 2, 5, 10 and $15 \mathrm{mg} / \mathrm{l})$ in combination with Kinetin $(0.5,1,2,5,10$ and $15 \mathrm{mg} / \mathrm{l})$. Results showed that using 6-Benzylaminopurine (BAP) was more effective than Kinetin in direct regeneration of potato. Low concentrations of BAP had the greatest effect on regeneration and also length of root and shoot but maximum numbers of somatic embryos were obtained in the presence of high a concentration of BAP. Using kinetin only influenced the number and length of regenerated shoots. Although Kinetin had no effect on the rate of regeneration but BAP increased it. There were significant differences among cultivars in all traits. Among tested cultivars, Marfona had the best direct regeneration ability in vitro condition. Therefore, it can be concluded that induction of direct organogenesis in potato is largely dependent on the genotype, and the use of BAP growth regulator plays an important role in inducing direct regeneration in potato cultivars.
\end{abstract}

Keywords: Callus culture, Organogenesis

1, 2, 3. MSc. Student, Assistant Professor and Professor, Respectively, Department of Plant Breeding and Biotechnology, Shahrekord University, Shahrekord, Iran.

*: Corresponding Author, Email: mrabiei@yandex.ru 